\title{
Role of omentin and vaspin in metabolic diseases in association with psoriasis
}

\section{Rola omentyny i waspiny w chorobach metabolicznych w powiązaniu z łuszczycą}

Paulina Kiluk, Anna Baran, Iwona Flisiak

Department of Dermatology and Venereology, Medical University of Bialystok, Poland

Klinika Dermatologii i Wenerologii Uniwersytetu Medycznego w Białymstoku, Polska

Dermatol Rev/Przegl Dermatol 2017, 104, 519-528 DOI: https://doi.org/l0.51 |4/dr.2017.71217

\author{
CORRESPONDING AUTHOR/ \\ ADRES DO KORESPONDENCJI: \\ lek. Paulina Kiluk \\ Klinika Dermatologii \\ i Wenerologii \\ Uniwersytet Medyczny \\ w Białymstoku \\ ul. Żurawia 14 \\ 15-540 Białystok, Polska \\ tel.: +48694259734 \\ e-mail: paulinakiluk@o2.pl
}

\begin{abstract}
Psoriasis is a chronic skin disease characterized by systemic inflammation associated with an increased risk of metabolic and cardiovascular complications. A special role in maintaining systemic inflammation is attributed to obesity. Adipose tissue is an active endocrine organ which, through adipokine secretion, is involved in the regulation of many systemic metabolic pathways. Obesity increases the risk of developing type 2 diabetes mellitus, atherosclerosis, cardiovascular diseases and hypertension. The paper presents the characteristics of two relatively recently discovered and little known adipokines: omentin and vaspin. They are considered to have beneficial effects preventing the development of metabolic disorders associated with obesity. In addition, attention was given to their possible involvement in the pathogenesis of psoriasis and potential use as markers of disease severity and the risk of developing metabolic complications.
\end{abstract}

\section{STRESZCZENIE}

Łuszczyca jest przewlekłą chorobą skóry, w której ogólnoustrojowy stan zapalny wiąże się ze zwiększonym ryzykiem rozwoju powikłań metabolicznych i sercowo-naczyniowych. Szczególne znaczenie w podtrzymaniu stanu zapalnego w organizmie ma otyłość. Tkanka tłuszczowa jest aktywnym organem endokrynnym, który poprzez wydzielane adipokiny bierze udział $\mathrm{w}$ regulacji licznych szlaków metabolicznych ustroju. Otyłość zwiększa ryzyko rozwoju cukrzycy typu 2, miażdżycy, chorób sercowo-naczyniowych oraz nadciśnienia. W pracy przedstawiono charakterystykę stosunkowo nowo odkrytych i mało poznanych adipokin: omentyny i waspiny, którym przypisuje się korzystne działanie, chroniące przed rozwojem zaburzeń metabolicznych towarzyszących otyłości. Ponadto zwrócono uwagę na ich potencjalny udział w patogenezie łuszczycy oraz możliwość wykorzystania jako markerów nasilenia choroby oraz ryzyka rozwoju powikłań metabolicznych.

Key words: obesity, psoriasis, adipokines, omentin, vaspin.

Słowa kluczowe: otyłość, łuszczyca, adipokiny, omentyna, waspina. 


\section{INTRODUCTION}

Psoriasis is a chronic inflammatory skin disease which is characterized by the hyperproliferation of keratinocytes and increased angiogenesis. The exact pathogenesis of psoriasis remains uncertain and continues to be a topic of extensive research. However, it has been postulated to involve a number of cytokines and proinflammatory factors. Chronic inflammatory process is a common denominator both for the cutaneous manifestation of the disease and the increased coexistence of metabolic disorders such as diabetes, hypercholesterolaemia, obesity, hypertension and cardiovascular complications [1].

In the age marked by a pandemic of obesity, increasing attention is paid to the role played by adipose tissue in the pathogenesis of systemic inflammation. In addition to serving as a reservoir of energy, adipose tissue is considered nowadays to be an important, and the largest, endocrine organ. Through the secretion of adipokines (including leptin, adiponectin, visfatin, resistin and newly discovered omentin) and cytokines (tumor necrosis factor- $\alpha$ (TNF- $\alpha$ ) and interleukin 6), adipose tissue exerts a powerful effect on internal organs, systemic metabolic pathways and the cardiovascular system. An excessive deposition of visceral adipose tissue is associated with elevated cholesterol and triglyceride levels and insulin resistance. It is also correlated with increased arterial blood pressure, thus heightening the risk of developing cardiovascular diseases $[2,3]$. Special attention is given to the problem of obesity in patients with psoriasis. Insufficient physical activity, and social isolation which often results from the stigmatization of patients, may contribute to an increased incidence of obesity in this group of patients. Adipokines secreted by adipose tissue can be involved not only in the maintenance of chronic inflammation - and thus an increase in the severity of psoriasis and the development of metabolic complications - but also in the pathogenesis of psoriasis. Determining the concentration of adipokines may therefore become a useful marker of disease severity and the risk of metabolic disorders.

The present study is concerned with two relatively new adipokines, omentin and vaspin, which demonstrate protective effects against the development of metabolic disorders. The study highlights their role in the body's metabolic processes, inflammatory diseases and psoriasis.

\section{OMENTIN}

Omentin is a relatively new adipokine which was isolated from the visceral adipose tissue by Yang $\mathrm{et}$ al. in 2003 [4]. It is produced primarily in the subpopulation of cells which are referred to collectively as the

\section{WPROWADZENIE}

Łuszczyca jest przewlekłą chorobą zapalną skóry, charakteryzującą się hiperproliferacją keratynocytów i wzmożoną angiogenezą. Dokładna patogeneza łuszczycy jest nieznana i pozostaje przedmiotem licznych badań, postuluje się jednak udział w jej rozwoju licznych cytokin i czynników prozapalnych. Przewlekły proces zapalny jest czynnikiem związanym zarówno ze skórną manifestacją choroby, jak i częstszym współwystępowaniem zaburzeń metabolicznych, takich jak cukrzyca czy hipercholesterolemia, a także otyłości, nadciśnienia tętniczego oraz powikłań sercowo-naczyniowych [1].

W czasach pandemii otyłości coraz większą uwagę zwraca się na udział tkanki tłuszczowej w patogenezie uogólnionego stanu zapalnego. Tkanka tłuszczowa nie tylko stanowi magazyn energii, lecz obecnie jest także traktowana jako ważny i największy organ endokrynny. Poprzez wydzielane adipokiny (m.in. leptynę, adiponektynę, wisfatynę, rezystynę, niedawno odkrytą omentynę) oraz cytokiny (czynnik martwicy nowotworu $\alpha$ (tumor necrosis factor- $\alpha$ - TNF- $\alpha$ ) i interleukinę 6) tkanka tłuszczowa silnie oddziałuje na narządy wewnętrzne, wewnątrzustrojowe szlaki metaboliczne oraz układ sercowo-naczyniowy. Nadmiar trzewnej tkanki tłuszczowej wiąże się ze wzrostem stężenia cholesterolu i triglicerydów, insulinoopornością oraz podwyższonymi wartościami ciśnienia tętniczego, co zwiększa ryzyko rozwoju chorób sercowo-naczyniowych [2, 3]. Zauważa się również problem otyłości u pacjentów z łuszczycą. Brak aktywności fizycznej i izolacja społeczna wynikająca często ze stygmatyzacji chorych może się przyczynić do częstszego występowania otyłości $\mathrm{w}$ tej grupie pacjentów. Adipokiny wydzielane przez tkankę tłuszczową mogą być zaangażowane nie tylko w podtrzymanie przewlekłego stanu zapalnego, nasilenie łuszczycy, rozwój powikłań metabolicznych, lecz także w jej patogenezę. Ich stężenie może stać się użytecznym markerem nasilenia choroby oraz ryzyka rozwoju schorzeń metabolicznych.

W niniejszej pracy przedstawiono dwie stosunkowo nowe adipokiny - omentynę i waspinę, które mają działanie ochronne w stosunku do zaburzeń metabolicznych. Ponadto podkreślono ich znaczenie $\mathrm{w}$ procesach metabolicznych organizmu, chorobach zapalnych oraz łuszczycy.

\section{OMENTYNA}

Omentyna jest stosunkowo nową adipokiną, wyodrębnioną z trzewnej tkanki tłuszczowej w $2003 \mathrm{r}$. przez Yanga i wsp. [4]. Produkowana jest przede wszystkim w obrębie subpopulacji komórek określanych mianem frakcji podporowo-naczyniowej 
adipose stromal-vascular cell fraction (SVF). The cells comprise preadipocytes, fibroblasts, endothelial cells and macrophages [5]. Furthermore, the expression of SVF has been demonstrated in endothelial cells, epicardial adipose tissue, thymus, small intestine, colon, reticulocytes, ovaries, lungs and placenta [5, 6]. Omentin is coded by two genes, omentin-1 and omentin-2, the former being the main circulating isoform. The omentin gene is located on chromosome 1q22-q23, which is associated with type 2 diabetes mellitus [7]. Based on that, omentin is implicated in the development of the disease [8]. Omentin is a protein with a molecular mass of $35 \mathrm{kDA}$, containing a 16 -amino acid long $N$-terminal signal peptide [5].

As the literature suggests, omentin has an anti-inflammatory role in the body [9-11]. The anti-inflammatory function is associated with its impact on a range of intracellular signal cascades. It inhibits cyclooxygenase-2 (COX-2) which becomes activated during inflammation. It prevents the activation of c-Jun $N$-terminal kinase (JNK), probably via the activation of signalling pathways engaging AMPK (5' adenosine monophosphate-activated protein kinase), endothelial nitric oxide synthase (eNOS) and nitric oxide (NO) [11]. Maruyama et al. have shown omentin to affect the functions of endothelial cells and the process of revasculatization in response to ischaemia through the stimulation of the kinase AkteNOS signalling pathway [12]. The anti-inflammatory activity is also linked to the suppressive effect of omentin on the extracellular signal-regulated kinase (ERK) and the nuclear factor-kB (NF-kB), thus inhibiting the TNF- $\alpha$ which induces intercellular adhesion molecules-1 (ICAM-1) and vascular cell adhesion molecules-1 (VCAM-1) [13]. Based on the mechanisms outlined above, omentin affects obesity-related metabolic and vascular disorders. The literature also suggests that the adipokine discussed is involved in the innate immune response and in the recognition of pathogens through the ability to bind to the bacterial capsular polysaccharides [14]. In this way, omentin may represent a specific link between the visceral adipose tissue and endothelial function, inflammatory and infectious factors [15].

On account of its anti-inflammatory activity and its potential applications in diagnostics and therapy omentin has been attracting a growing interest in various areas of medicine. For example, the concentration of the protein has been found to be decreased in patients with active Crohn's disease. In fact, the concentration of omentin correlated better with the severity of inflammatory bowel disease than the concentration of C-reactive protein. Hence, determining the serum concentration of omentin may serve as a potential marker for the presence and activity of IBD $[16,17]$. tkanki tłuszczowej (adipose stromal-vascular cell fraction - SVF). Do komórek tych zalicza się preadipocyty, fibroblasty, komórki śródbłonka i makrofagi [5]. Ponadto wykazano jej ekspresję w komórkach śródbłonka, tkance tłuszczowej nasierdziowej, grasicy, jelicie cienkim, okrężnicy, retikulocytach, jajnikach, płucach i łożysku [5,6]. Omentyna jest kodowana przez dwa geny - omentyny 1 i omentyny $2, \mathrm{z}$ których pierwsza jest główną krążącą izoformą. Gen omentyny zlokalizowany jest na chromosomie 1q22-q23, który wiąże się z cukrzycą typu 2 [7]. Sugeruje się jej udział w rozwoju tego schorzenia [8]. Omentyna jest białkiem o masie cząsteczkowej $35 \mathrm{kDa}$, zawierającym 16-aminokwasowy $N$-terminalny peptyd sygnałowy [5].

Omentyna, jak opisano w piśmiennictwie, odgrywa w organizmie rolę przeciwzapalną [9-11]. Funkcja przeciwzapalna wiąże się z oddziaływaniem na szereg wewnątrzkomórkowych kaskad sygnalizacyjnych. Hamuje cyklooksygenazę-2 (COX-2) aktywowaną w stanach zapalnych. Zapobiega aktywacji kinazy c-Jun $N$-terminalnej (JNK), prawdopodobnie poprzez aktywację szlaków sygnałowych angażujących AMPK (kinaza aktywowana przez adenozyno-5'-monofosforan), śródbłonkową syntazę tlenku azotu (eNOS) i tlenek azotu (NO) [11]. Maruyama i wsp. wykazali wpływ omentyny na funkcje komórek śródbłonka oraz proces rewaskularyzacji w odpowiedzi na niedokrwienie poprzez stymulację szlaku sygnałowego kinazy Akt-eNOS [12]. Działanie przeciwzapalne wiąże się także z supresyjnym oddziaływaniem omentyny na kinazę regulowaną zewnątrzkomórkowo (ERK) oraz czynnik jądrowy кB (nuclear factor $\kappa B-N F-\kappa B$ ). W ten sposób hamuje ona TNF- $\alpha$, który indukuje cząsteczki adhezji międzykomórkowej 1 (intercellular adhesion molecule-1 - ICAM-1) i cząsteczki adhezji komórkowej naczyń (vascular cell adhesion molecule-1 - VCAM-1) [13]. Poprzez powyższe mechanizmy omentyna oddziałuje na związane z otyłością zaburzenia metaboliczne oraz naczyniowe. W piśmiennictwie sugeruje się także udział tej adipokiny we wrodzonej odpowiedzi immunologicznej i rozpoznawaniu patogenów poprzez zdolność do wiązania z polisacharydami otoczek bakteryjnych [14]. Omentyna może stanowić swego rodzaju łącznik między trzewną tkanką tłuszczową a funkcją śródbłonka, czynnikami zapalnymi i infekcyjnymi [15].

Ze względu na działanie przeciwzapalne oraz możliwe wykorzystanie w diagnostyce i terapii omentyna wzbudza coraz większe zainteresowanie różnych dziedzin medycyny. Stwierdzono zmniejszone stężenie tego białka u pacjentów $\mathrm{z}$ aktywną chorobą Leśniowskiego-Crohna, które w większym stopniu korelowało z nasileniem choroby zapalnej jelit niż stężenie białka C-reaktywnego. Dlatego też oznaczanie 
What is more, low omentin concentrations have been detected in the synovial fluid in patients with osteoarthritis, which points to the usefulness of omentin as a biomarker for determining the stage of the degenerative process [18].

As the civilization advances, metabolic disorders such as obesity, type 2 diabetes mellitus or atherosclerosis, are becoming some of the most widespread health problems. Therefore, it seems reasonable to search for new methods that make it possible to diagnose the disorders at an early stage. The above applies in particular to insulin resistance. Obesity is associated with a decrease in the plasma concentration and mRNA expression of omentin in adipose tissue [19]. Negative correlations have been identified for the concentration of adipokine and body mass index (BMI), waist circumference and insulin resistance. Positive correlations have been found with the concentration of HDL cholesterol and plasma adiponectin [20]. Interesting findings have been reported by Bremer et al., including a reduced concentration of omentin in the serum and subcutaneous adipose tissue in patients with metabolic syndrome (MS) in relation to the control group, regardless of obesity [21]. Omentin increases insulin sensitivity by stimulating insulin-dependent glucose uptake in subcutaneous and visceral adipose tissue cells, muscles and liver [5]. A low concentration of omentin is linked to an increasing insulin resistance, abnormal glucose tolerance and the development of type 2 diabetes mellitus [22]. Obesity is a strong cardiovascular risk factor, so further research focused on the role of omentin in slimming is necessary.

It is thought that disorders of the body's metabolic processes associated with insulin resistance and obesity play a role in the pathogenesis of polycystic ovary syndrome (PCOS). Yang et al. have found a reduced omentin concentration in a group of non-obese women with PCOS, compared to a healthy control group, suggesting that insulin resistance may contribute to a further decrease in the concentration of omentin regardless of body weight [23].

Also, several studies have revealed an increased omentin concentration in patients with cancer (e.g. of the liver, prostate and colon), irrespective of their BMI and blood concentrations of lipids and glucose. Higher adipokine concentrations have also been detected in patients with pancreatic adenocarcinoma, with a positive correlation found between an increase in its concentration and tumour mass. Such observations may suggest the use of the protein in screening tests for early cancer detection [24-27]. Omentin is also attracting a growing interest in the context of the development of cardiovascular diseases. Endothelial dysfunction initiates the process of atherogenesis. Omentin is believed to have an antiatherosclerotic effect by stimulating NO production by the endothe- stężenia omentyny w surowicy może posłużyć jako potencjalny marker obecności i aktywności choroby zapalnej jelit $[16,17]$.

Ponadto małe stężenie omentyny stwierdzono w płynie maziowym pacjentów z chorobą zwyrodnieniową stawów, co sugeruje znaczenie tej substancji jako biomarkera zaawansowania procesu zwyrodnienia [18].

Wraz z postępem cywilizacyjnym zaburzenia metaboliczne, takie jak otyłość, cukrzyca typu 2 oraz miażdżyca, stają się jednym $z$ głównych problemów zdrowotnych. Uzasadnione jest więc poszukiwanie nowych metod umożliwiających diagnostykę tych zaburzeń na wczesnym etapie, zwłaszcza insulinooporności. W otyłości zmniejsza się osoczowe stężenie oraz ekspresja mRNA omentyny w tkance tłuszczowej trzewnej [19]. Wykazano negatywną korelację stężenia adipokiny ze wskaźnikiem masy ciała (body mass index - BMI), obwodem talii, insulinoopornością, natomiast pozytywną ze stężeniem cholesterolu frakcji HDL oraz osoczowej adiponektyny [20]. Interesujące spostrzeżenia przedstawili Bremer i wsp. stwierdzili zmniejszone stężenie omentyny w surowicy i podskórnej tkance tłuszczowej u osób z zespołem metabolicznym (ZM) w porównaniu z grupą kontrolną, niezależnie od otyłości [21]. Omentyna zwiększa insulinowrażliwość poprzez stymulację insulinozależnego wychwytu glukozy w komórkach tłuszczowych tkanki podskórnej i trzewnej, w mięśniach i wątrobie [5]. Jej małe stężenie wiąże się z narastającą insulinoopornością, nieprawidłową tolerancją glukozy oraz rozwojem cukrzycy typu 2 [22]. Otyłość jest silnym czynnikiem ryzyka sercowo-naczyniowego, konieczne są więc dalsze badania nad rolą omentyny w odchudzaniu.

Uważa się, że zaburzenia prawidłowych przemian metabolicznych w organizmie związane $\mathrm{z}$ insulinoopornością oraz otyłością odgrywają rolę w patogenezie zespołu policystycznych jajników (polycystic ovary syndrome - PCOS). Yang i wsp. stwierdzili zmniejszone stężenie omentyny u kobiet z PCOS bez otyłości w porównaniu ze zdrową grupą kontrolną. Autorzy sugerują, że insulinooporność może się przyczynić do dalszej redukcji stężenia omentyny, niezależnie od masy ciała [23].

Z kolei w kilku badaniach wykazano zwiększone stężenie omentyny u pacjentów $\mathrm{z}$ chorobą nowotworową, m.in. wątroby, prostaty, okrężnicy, niezależnie od BMI, stężenia lipidów oraz glukozy we krwi. Większe stężenie adipokiny stwierdzono także u chorych z gruczolakorakiem trzustki, a wzrost jej stężenia dodatnio korelował z masą guza. Obserwacje te mogą sugerować wykorzystanie tego białka w badaniach przesiewowych w kierunku wczesnego wykrycia nowotworów [24-27]. Omentyna wzbudza coraz większe zainteresowanie w związku z choro- 
lium, halting oxidative stress and inflammation through TNF- $\alpha$ inhibition, suppression of monocyte adhesion to endothelial cells by inhibiting the expression of ICAM-1 and VCAM-1 [28, 29]. Through endothelial nitric acid, adipokine shows a vasodilatory effect [30]. Its plasma concentration may thus become a marker of endothelial function [31]. In addition, Ouwens et al. have demonstrated an increased expression of omentin in the epicardial tissue. The authors presume that omentin counteracts the formation of atheromatous plaque in coronary vessels and has a beneficial effect on other disorders pathogenetically linked to obesity, such as arterial hypertension, in relation to the omentin-induced vasodilatory effect [32]. A negative correlation has been identified between the concentration of omentin and the thickness of the intima-media complex in carotid arteries, their stiffness, BMI, waist circumference, systolic arterial pressure, fasting blood glucose level and the insulin resistance index HOMA-IR (homeostasis model assessment of insulin resistance). Consequently, omentin is closely linked to the metabolic syndrome and its deficiency plays a significant role in the development of atheromatosis in these patients [33-35]. Zhong et al. have demonstrated lower plasma levels of omentin in patients with acute coronary syndrome (ACS) or stable angina pectoris than in the control group. Another observation made by the authors was that patients with ACS had lower omentin levels than individuals with stable angina [36]. According to most recent reports, higher plasma concentrations of omentin are associated with better developed coronary collateral circulation (CCC). The observation points to the possibility of using omentin as a marker of well-developed CCC in patients with the narrowing of coronary vessels of $90 \%$ or more [37].

Currently, more and more attention is being focused on the increased incidence of metabolic disorders in patients with psoriasis. Zhang et al. have shown a significant reduction in omentin-1 concentration in patients with psoriasis compared to the healthy control group, and a negative correlation between the concentration of omentin and the severity of the disease as measured by PASI (Psoriasis Area and Severity Index). At the same time, however, the authors have not observed a correlation between the concentration of omentin and the duration of the disease. In addition, based on immunohistochemical analyses of skin biopsies, they have noted a lower expression of the adipokine in the epidermis of psoriatic skin than in healthy skin [38]. Similar observations of a decreased concentration of plasma omentin in patients with psoriasis, and its negative correlation with PASI, have been made by Takahashi et al. The authors have also observed an elevated concentration of the adipokine after the treatment of skin lesions, which sug- bami sercowo-naczyniowymi. Zaburzenie funkcjonowania śródbłonka inicjuje proces aterogenezy. Uważa się, że omentyna ma właściwości przeciwmiażdżycowe ze względu na stymulację produkcji NO przez śródbłonek, hamowanie stresu oksydacyjnego oraz zapalenia na drodze inhibicji TNF- $\alpha$, supresję adhezji monocytów do komórek śródbłonka poprzez hamowanie ekspresji ICAM-1 oraz VCAM-1 [28, 29]. Adipokina za sprawą endotelialnego NO działa rozszerzająco na naczynia krwionośne [30]. Jej osoczowe stężenie może być markerem funkcji śródbłonka [31]. Ponadto Ouwens i wsp. wykazali zwiększoną ekspresję omentyny w tkance nasierdziowej. Autorzy ci przypuszczają, że adipokina przeciwdziała tworzeniu się blaszki miażdżycowej w naczyniach wieńcowych oraz korzystnie wpływa na inne zaburzenia patogenetycznie powiązane $\mathrm{z}$ otyłością, takie jak nadciśnienie tętnicze, w związku z wykazywanym przez nią efektem wazodylatacyjnym [32]. Stwierdzono negatywną korelację stężenia omentyny z grubością kompleksu intima-media tętnic szyjnych, ich sztywnością, BMI, obwodem talii, skurczowym ciśnieniem tętniczym, stężeniem glukozy na czczo oraz wskaźnikiem insulinooporności HOMA-IR (homeostasis model assessment of insulin resistance). Dlatego też omentyna jest ściśle związana z ZM, a jej niedobór odgrywa znaczącą rolę w rozwoju miażdżycy u tych pacjentów [33-35]. Zhong i wsp. wykazali mniejsze stężenia osoczowej omentyny u chorych z ostrym zespołem wieńcowym (OZW) lub stabilną dławicą piersiową w stosunku do grupy kontrolnej. Dodatkowo badacze zaobserwowali, że u chorych z OZW były one mniejsze niż u osób ze stabilną dławicą [36]. Zgodnie z najnowszymi doniesieniami większe osoczowe stężenie omentyny wiąże się z lepiej rozwiniętym wieńcowym krążeniem obocznym (coronary collateral circulation - CCC). Możliwe jest więc jej zastosowanie jako markera odpowiednio rozwiniętego CCC u pacjentów z ponad 90-procentowym zwężeniem naczyń wieńcowych [37].

Obecnie coraz większą uwagę poświęca się częstszemu występowaniu zaburzeń metabolicznych u osób z łuszczycą. Zhang i wsp. wykazali znacząco zmniejszone stężenie omentyny $1 \mathrm{u}$ chorych na łuszczycę w porównaniu ze zdrową grupą kontrolną oraz negatywną korelację jej stężenia z nasileniem choroby mierzonym PASI (Psoriasis Area and Severity Index). Jednocześnie badacze nie zauważyli związku stężenia omentyny z czasem trwania choroby. Ponadto na podstawie badania immunohistochemicznego biopsji skórnych stwierdzili mniejszą ekspresję tej adipokiny w naskórku ze zmian łuszczycowych w porównaniu ze zdrową skórą [38]. Podobnych spostrzeżeń - zmniejszone stężenie osoczowej omentyny u pacjentów z łuszczycą oraz jego negatywna korelacja z PASI - dokonali także Takahashi i wsp. Zaobser- 
gests that it may be useful as a marker of treatment efficacy [39]. In another study, the same authors have found an increased incidence of insulin resistance and diabetes mellitus in patients with psoriasis as compared to patients with other dermatoses. A low concentration of omentin in psoriasis may contribute to the development of insulin resistance in these patients $[39,40]$. Ismail and Mohamed have also highlighted lower concentrations of omentin in psoriatic patients. Taking into account the protective role of omentin both in the prevention of atheromatous plaque deposition in coronary vessels and the development of other obesity-related vascular disorders, the researchers have suggested that low omentin levels in patients with psoriasis may be a factor contributing to a greater incidence of vascular complications in this patient group [41, 42]. The studies presented above suggest that a low concentration of omentin may be a factor in the emergence of inflammation, which in turn may contribute both to the development of psoriasis and metabolic and vascular disorders accompanying it.

\section{VASPIN}

Vaspin (VASP) is a relatively little known adipokine which was first isolated in 2005 from the visceral adipose tissue of OLETF (Otsuka Long-Evans Tokushima Fatty) strain rats in the animal model of visceral obesity accompanied by type 2 diabetes mellitus. The VASP-encoding gene (OL-64) is located on the long arm of chromosome 14 (14q32.1). Vaspin is a protein with a molecular mass of $45.2 \mathrm{kDA}$, consisting of 395 amino acids [43]. It belongs to the family of serine protease inhibitors (serpins). Serpins inhibit serine proteases via a unique mechanism of suicide inactivation. They have a reactive centre loop (RCL) consisting of approximately a dozen amino acid residues which is presented to an appropriate protease as a pseudosubstrate for proteolysis. The RCL/protease complex triggers a conformational change in the serpin, which deforms the reactive centre of protease, at the same time causing protease inactivation. The modified serpin increases the sensitivity to proteolysis of the inhibited protease, while permanently losing its catalytic ability [43,44]. Vaspin expression has been found in visceral and subcutaneous white adipose tissue in obese patients with normal glucose tolerance, and has been shown to increase along with rising body fat percentage and BMI [45]. Also, Klöting et al. have detected a higher expression of VASP in the adipose tissue of patients with type 2 diabetes mellitus than in individuals without disorders of carbohydrate metabolism [46]. Interestingly, a relatively high expression of VASP mRNA has been found in the skin $[43,46]$. Furthermore, the serum concentrations of VASP have been shown to be higher in wom- wowali oni wzrost stężenia adipokiny po leczeniu zmian skórnych i zasugerowali jej wykorzystanie jako markera skuteczności terapii [39]. W innej pracy tych samych autorów stwierdzono częstsze występowanie insulinooporności i cukrzycy u chorych na łuszczycę w porównaniu z pacjentami z innymi dermatozami. Małe stężenie omentyny w łuszczycy może się przyczynić do rozwoju insulinooporności u tych pacjentów $[39,40]$. Także Ismail i Mohamed zwrócili uwagę na mniejsze stężenie omentyny u chorych na łuszczycę. Ze względu na jej protekcyjną rolę w przeciwdziałaniu tworzeniu się blaszki miażdżycowej w naczyniach wieńcowych i w rozwoju innych zaburzeń naczyniowych wynikających z otyłości badacze zasugerowali, że jej małe stężenie u pacjentów z łuszczycą może się przyczyniać do częstszego występowania powikłań naczyniowych u tych chorych $[41,42]$. Przedstawione badania wykazują, że małe stężenie omentyny może odgrywać rolę w powstawaniu stanu zapalnego, co z kolei może powodować rozwój zarówno łuszczycy, jak i towarzyszących jej zaburzeń metabolicznych i naczyniowych.

\section{WASPINA}

Waspina (VASP) jest stosunkowo mało poznaną adipokiną, która została wyizolowana z wisceralnej tkanki tłuszczowej szczurów szczepu OLETF (Otsuka Long-Evans Tokushima Fatty), zwierzęcego modelu otyłości brzusznej przebiegającej z cukrzycą typu 2 w 2005 r. Gen kodujący VASP (OL-64) zlokalizowany jest na długim ramieniu chromosomu 14 (14q32.1). Waspina jest białkiem o masie cząsteczkowej 45,2 kDa, zbudowanym z 395 aminokwasów [43]. Należy do rodziny inhibitorów proteazy serynowej (serpin). Serpiny hamują proteazy serynowe poprzez unikalny mechanizm tzw. samobójczego wabika. Mają zbudowaną z kilkunastu reszt aminokwasowych pętlę reaktywną (reactive centre loop - RCL), prezentowaną właściwej proteazie jako pseudosubstrat do proteolizy. Połączenie RCL z proteazą wywołuje zmianę konformacji serpiny, przez co deformuje centrum reaktywne proteazy, jednocześnie ją inaktywując. Zmieniona serpina zwiększa wrażliwość na proteolizę hamowanej proteazy i równocześnie trwale traci zdolności katalityczne [43, 44]. Ekspresję VASP stwierdzono w białej tkance tłuszczowej podskórnej i trzewnej u osób otyłych z prawidłową tolerancją glukozy. Zwiększała się ona wraz ze wzrostem procentowej zawartości tłuszczu i BMI [45]. Z kolei Klöting i wsp. wykazali wyższą ekspresję VASP w tkance tłuszczowej u osób z cukrzycą typu 2 niż u osób bez zaburzeń gospodarki węglowodanowej [46]. Ponadto stosunkowo wysoką ekspresję mRNA VASP stwierdzono w obrębie skóry $[43,46]$. Zwrócono uwagę na większe stężenie VASP w surowicy 
en than in men with normal glucose tolerance [47]. The target receptors and molecular mechanisms of VASP activity are as yet unknown, however experimental studies have demonstrated an improvement in glucose tolerance and insulin sensitivity after the administration of VASP [43]. The literature reports suggest that an increase in VASP expression may constitute a compensatory mechanism in response to an increase in obesity and insulin resistance $[46,48]$. Furthermore, in patients with type 2 diabetes mellitus a positive correlation has been shown between the serum VASP concentration and the level of glycated haemoglobin $\left(\mathrm{HbA}_{1 \mathrm{c}}\right)$ defining the degree of diabetic control [49]. The beneficial activity of VASP, which increases the sensitivity of adipose tissue to insulin, requires further research. Further observations and analysis are also needed to assess the possibility of using VASP concentration as a biomarker of insulin resistance syndrome in obese individuals.

Some authors also suggest that VASP has a beneficial antiatherosclerotic activity which protects vascular endothelial cells against apoptosis induced by free fatty acids [50]. A low concentration of the adipokine also correlates with the severity of coronary heart disease and unstable angina pectoris [51]. According to Maijer et al., determining the concentration of VASP may be helpful in the assessment of the risk of rheumatoid arthritis in patients with a positive rheumatoid factor test and the presence of anti-citrulline antibodies [52]. Saalbach et al. have confirmed the expression of VASP mRNA in the skin, particularly in keratinocytes. The researchers have observed a decreased expression in the epidermis, within psoriatic lesions, compared to unaffected skin areas in the same patients, which may reflect the disorders of keratinocyte differentiation in psoriasis. The study suggested a possible implication of VASP in the persistence of psoriatic lesions as an expression of imbalance between proteases and their inhibitors engaged in processes of exfoliation and regulation of inflammation [53]. In another study, conducted by Saalbach et al., the researchers have confirmed a markedly decreased expression of VASP within the epidermis of psoriatic lesions in comparison to the skin of healthy individuals. They have also found that the expression of the adipokine in keratinocytes is correlated with the differentiation of keratinocytes and decreases under the influence of pronounced proliferation and stimulation by proinflammatory factors such as TNF- $\alpha$, IL-17, IL-20, IL-6, i.e. processes involved in the pathogenesis of psoriasis. The authors claim that the expression of VASP in keratinocytes takes part in reducing inflammation in the skin and may play a significant role in the emergence of chronic inflammatory skin diseases, one of them being psoriasis [54]. Further research is needed to establish the link u kobiet niż u mężczyzn z prawidłową tolerancją glukozy [47]. Nieznane są jeszcze receptory docelowe oraz molekularne mechanizmy jej działania, niemniej w badaniach doświadczalnych obserwowano poprawę tolerancji glukozy i insulinowrażliwości po podaniu VASP [43]. W piśmiennictwie sugeruje się, że wzrost ekspresji VASP może stanowić mechanizm kompensacyjny, w odpowiedzi na nasilenie otyłości oraz insulinooporności $[46,48]$. Ponadto u osób z cukrzycą typu 2 wykazano dodatnią korelację między stężeniem VASP w surowicy i wartością hemoglobiny glikowanej $\left(\mathrm{HbA}_{1 \mathrm{c}}\right)$ określającej stopień wyrównania cukrzycy [49]. Korzystne działanie VASP polegające na uwrażliwianiu tkanki tłuszczowej na insulinę wymaga dalszych badań. Należy poddać obserwacji i analizie jej stężenia u osób otyłych - jako biomarker zespołu oporności na insulinę.

Niektórzy autorzy sugerują także korzystne działanie przeciwmiażdżycowe VASP, która chroni komórki śródbłonka naczyniowego przed apoptozą wywołaną przez wolne kwasy tłuszczowe [50]. Małe stężenie tej adipokiny koreluje również z nasileniem choroby naczyń wieńcowych oraz niestabilnej dławicy piersiowej [51]. Według Maijera i wsp. oznaczenie stężenia VASP może być pomocne w ocenie ryzyka rozwoju reumatoidalnego zapalenia stawów u osób z dodatnim czynnikiem reumatoidalnym i obecnością przeciwciał antycytrulinowych [52]. Saalbach i wsp. potwierdzili ekspresję mRNA VASP w skórze, zwłaszcza w keratynocytach. Badacze zauważyli zmniejszoną jej ekspresję w naskórku w obrębie zmian łuszczycowych w porównaniu z niezajętymi obszarami skóry u tych samych pacjentów, co może świadczyć o zaburzeniach w różnicowaniu keratynocytów w łuszczycy. W badaniu zasugerowano udział VASP w podtrzymaniu zmian łuszczycowych jako wyraz zaburzenia równowagi między proteazami a ich inhibitorami zaangażowanymi w procesy złuszczania oraz regulacji stanu zapalnego [53]. W badaniu przeprowadzonym przez Saalbacha i wsp. potwierdzono znacząco obniżoną ekspresję VASP w obrębie naskórka ze zmian łuszczycowych w porównaniu ze skórą osób zdrowych. Ponadto autorzy stwierdzili, że ekspresja adipokiny w keratynocytach koreluje $\mathrm{z}$ różnicowaniem keratynocytów i zmniejsza się pod wpływem nasilonej proliferacji i stymulacji przez czynniki prozapalne, takie jak TNF- $\alpha$, IL-17, IL-20, IL-6, czyli procesów zaangażowanych w patogenezę łuszczycy. Według autorów ekspresja VASP w keratynocytach uczestniczy w ograniczaniu stanu zapalnego w skórze i może odgrywać istotną rolę w powstawaniu przewlekłych chorób zapalnych skóry, m.in. łuszczycy [54]. Ustalenie związku stężenia VASP z nasileniem zmian łuszczycowych oraz możliwość wykorzystania działania przeciwzapalnego omawianej adipokiny w leczeniu łuszczycy wymaga 
between the concentration of VASP and the severity of psoriatic lesions, and determine the possibility of using the anti-inflammatory activity of the adipokine concerned in the therapy of psoriasis. Atasaven and Kesli argue that VASP may not only serve as a marker for psoriasis but also its concentration may correlate positively with the severity of skin lesions [55].

\section{SUMMARY}

Numerous studies have shown that adipose tissue is an active endocrine organ that synthesizes multiple biologically active proteins - adipokines. Not all of them have a proinflammatory function in the body. The adipokines discussed above, omentin and VASP, play a role in inducing the body's beneficial metabolic processes. The observations presented in the study point to the likely involvement of omentin and VASP in the development and maintenance of chronic inflammation in psoriasis and to their possible use as biological markers of disease development and severity. However, further research is needed to elucidate the role of omentin and VASP in the pathogenesis of both psoriasis and metabolic disorders. Based on that, it would be possible in the future to develop targeted therapeutic strategies both for the treatment of psoriasis and for the reduction of the risk of developing metabolic complications in the patients. In the light of the studies, special attention should be paid to body weight reduction in psoriatic patients, not only to prevent or delay the emergence of metabolic diseases, but also to contribute to an improved efficacy of psoriasis treatment.

\section{CONFLICT OF INTEREST}

The authors declare no conflict of interest. dalszych badań. Według Atasavena i Kesliego VASP nie tylko może być markerem łuszczycy, lecz także jej stężenie może dodatnio korelować z nasileniem zmian skórnych [55].

\section{PODSUMOWANIE}

Liczne badania potwierdzają, że tkanka tłuszczowa jest aktywnym organem endokrynnym syntetyzującym liczne biologicznie aktywne białka - adipokiny. Nie wszystkie pełnią w organizmie funkcję prozapalną. Przedstawione adipokiny (omentyna i VASP) odgrywają rolę $\mathrm{w}$ indukowaniu korzystnych procesów metabolicznych w organizmie. Przedstawione w pracy obserwacje wskazują na prawdopodobny udział omentyny i VASP w rozwoju i podtrzymaniu przewlekłego stanu zapalnego w łuszczycy oraz na możliwość ich wykorzystania jako biologicznych markerów rozwoju i nasilenia choroby. Konieczne są jednak dalsze badania nad dokładną rolą omentyny i VASP w patogenezie zarówno łuszczycy, jak i zaburzeń metabolicznych. Pozwoli to w przyszłości na stworzenie ukierunkowanych strategii leczenia łuszczycy i zmniejszenie ryzyka rozwoju powikłań metabolicznych $\mathrm{u}$ tych chorych. W świetle przedstawionych badań szczególną uwagę należy zwrócić na redukcję masy ciała u pacjentów z łuszczycą, ponieważ nie tylko może to zapobiec lub opóźnić wystąpienie chorób metabolicznych, lecz także przyczynić się do poprawy efektów leczenia samej łuszczycy.

\section{KONFLIKT INTERESÓW}

Autorzy deklarują brak konfliktu interesów.

\section{References \\ Piśmiennictwo}

1. Boehncke W.H., Boehncke S., Tobin A.M., Kirby B.: The "psoriatic march": a concept of how severe psoriasis may drive cardiovascular comorbidity. Exp Dermatol 2011, 20, 303-307.

2. Hulthe J., Hulten L.M., Fagerberg B.: Low adipocyte-derived plasma protein adiponectin concentrations are associated with the metabolic syndrome and small dense low-density lipoprotein particles: atherosclerosis and insulin resistance study. Metabolism 2003, 52, 1612-1614.

3. Kanai H., Matsuzawa Y., Kotani K.: Close correlation of intra-abdominal fat accumulation to hypertension in obese women. Hypertension 1990, 16, 484-490.

4. Yang R.Z., Shuldiner A.R., Gong D.W.: Cloning of omentin, a new adipokine from human omental fat tissue. Diabetes 2003, 52, 1-A730.

5. Yang R.Z., Lee M.J., Hu H., Pray J., Wu H.B., Hansen B.C., et al.: Identification of omentin as a novel depot-specific adipokine in human adipose tissue: possible role in modulating insulin action. Am J Physiol Endocrinol Metab 2006, $290,1253-1261$.

6. Nakamura K., Fuster J.J., Walsh K.: Adipokines: a link between obesity and cardiovascular disease. J Cardiol 2014, 63, $250-259$.

7. Havel P.J.: Update on adipocyte hormones: regulation of energy balance and carbohydrate/lipid metabolism. Diabetes 2004, 53 Suppl 1: S143-S151.

8. Fu M., Gong D.W., Damcott C., Sabra M., Yang R., Pollin T.I., et al.: Systematic analysis of omentin 1 and omentin 2 on 1 q23 as candidate genes for type 2 diabetes in the old older amish. Diabetes 2004, 53, A59.

9. Tan B.K., Adya R., Randeva H.S.: Omentin: a novel link between inflammation, obesity and cardiovascular disease. Trends Cardiovasc Med 2010, 20, 143-148.

10. Sengul E., Duygulu G., Dindar S., Bunul F.: Serum omentin-1, inflammation and carotid atherosclerosis in patients with nondiabetic chronic kidney diseases. Ren Fail 2013, 35, 1089-1093. 
11. Yamawaki H., Kuramoto J., Kameshima S., Usui T., Okada M., Hara Y.: Omentin, a novel adipocytokine inhibits TNFinduced vascular inflammation in human endothelial cells. Biochem Biophys Res Commun 2011, 408, 339-343.

12. Mauyama S., Shibata R., Kikuchi R., Izumiya Y., Rokutanda T., Araki S., et al.: Fat-derived factor omentin stimulates endothelial cell function and ischemia-induced revascularization via endothelial nitric oxide synthase-dependent mechanism. J Biol Chem 2012, 287, 408-417.

13. Brunetti L., Leone S., Orlando G., Ferrante C., Recinella L., Chiavaroli A., et al.: Hypotensive effects of omentin-1 related to increased adiponectin and decreased interleukin-6 in intra-thoracic pericardial adipose tissue. Pharmacol Rep 2014, 66, 991-995.

14. Gerwick L., Corley-Smith G., Bayne C.J.: Gene transcript changes in individual rainbow trout livers following an inflammatory stimulus. Fish Shellfish Immunol 2007, 22, 157-171.

15. Szopa M., Skupień J.: Omentyna - nowa adipokina w kontekście założeń nowej definicji zespołu metabolicznego (IDF 2005). Diabetol Prakt 2007, 8, 35-39.

16. Yin J., Hou P., Wu Z., Nie Y.: Decreased levels of serum omentin-1 in patients with inflammatory bowel disease. Med Sci Monit 2015, 21, 118-122.

17. Schaffer A., Zeitoun M., Wobser H., Buechler C., Aslanidis C., Herfarth H.: Frequency and significance of the novel single nuclotide missence polymorphism Val109Asp in the human gene encoding omentin in Caucasian patients with type 2 diabetes mellitus or chronic inflammatory bowel disease. Cardiovasc Diabetol 2007, 6, 3.

18. Xu L., Zhu G.B., Wang L., Wang D.F., Jianq X.R.: Synovial fluid omentin-1 levels are inversely correlated with radiographic severity of knee osteoarthritis. Invest Med 2012, 60, 583-586.

19. Barth S., Klein P., Horbach T., Dötsch J., Rauh M., Rascher W., et al.: Expression of neuropeptide $Y$, omentin and visfatin in visceral and subcutaneous adipose tissues in humans: relation to endocrine and clinical parameters. Obes Facts 2010, 3, $245-251$.

20. Batista Souza C.M., Yang R.Z., Lee M.J., Glynn M.N., Yu D.Z., Pray J., et al.: Omentin plasma levels and genes expression are decressed in obesity. Diabetes 2007, 56, 1655-1661.

21. Bremer A.A., Jialal I.: Adipose tissue dysfunction in nascent metabolic syndrome. J Obes 2013, $2013,393192$.

22. Pan H.Y., Guo L., Li Q.: Changes of serum omentin-1 levels in normal subjects and in patients with impaired glucose regulation and with newly diagnosed and untreated type 2 diabetes. Diabetes Res Clin Pract 2010, 88, 29-33.

23. Yang H.Y., Ma Y., Lu X.H., Liang X.H., Suo Y.J., Huang Z.X., et al.: The correlation of plasma omentin-1 with insulin resistance in non-obese polycystic ovary syndrome. Ann Endocrinol 2015, 76, 620-627.

24. Zhang Y.Y., Zhou L.M.: Omentin-1, a new adipokine, promotes apoptosis through regulating Sirt1-dependent p53 deacetylation in hepatocellular carcinoma cells. Eur J Pharmacol 2013, 698, 137-144

25. Uyeturk U., Sarici H., Kin Tekce B., Eroglu M., Kemahli E., Uyeturk U., et al.: Serum omentin level in patients with prostate cancer. Med Oncol 2014, 31, 923

26. Uyeturk U., Alcelik A., Aktas G., Tekce B.K.: Post-treatment plasma omentin levels in patients with stage III colon carcinoma. J BUON 2014, 19, 681-685.

27. Karabulut S., Afsar C.U., Karabulut M., Alis H., Bozkurt M.A., Aydogan F., et al.: Clinical significance of serum omentin-1 levels in patients with pancreatic adenocarcinoma. BBA Clin 2016, 6, 138-142.

28. Zhong X., Li X., Liu F.. Tan H., Shang D.: Omentin inhibits TNF-alpha-induced expression of adhesion molecules in endothelial cells via ERK/NF-kappaB pathway. Biochem Biophys Res Commun 2012, 425, 401-406.

29. Yamawaki H.: Vascular effects of novel adipocytokines: focus on vascular contractility and inflammatory responses. Biol Pharm Bull 2011, 34, 307-310.

30. Yamawaki H., Tsubaki N., Mukohda M., Okada M., Hara Y.: Omentin, a novel adipokine, induces vasodilatation in rat isolated blood vessels. Biochem Biophys Res Commun 2010, 393, 668-672.

31. Moreno-Navarrete J.M., Ortega F., Castro A., Sabater M., Ricart W., Fernandez-Real J.M.: Circulating omentin as a novel biomarker of endothelial dysfunction. Obesity 2011, 19, 1552-1559.

32. Ouwens D.M., Sell H., Greulich S., Eckel J.: The role of epicardial and perivascular adipose tissue in the pathophysiology of cardiovascular disease. J Cell Mol Med 2010, 14, 2223-2234

33. Van de Voorde J., Pauwels B., Boydens C., Decaluwe K.: Adipocytokines in relation to cardiovascular disease. Metabolism 2013, 62, 1513-251.

34. Liu R., Wang X., Bu P.: Omentin-1 is associated with carotid atherosclerosis in patients with metabolic syndrome. Diabetes Res Clin Pract 2011, 93, 21-25.

35. Bley T.A., Johnson K.M., Francois C.J., Reeder S.B., Schibler M.L., Landgraf B.: Noninvasive assessment of transstenotic pressure gradients in porcine renal artery stenoses by using vastly undersampled phase-contrast MR angiography. Radiology 2011, 261, 266-273.

36. Zhong X., Zhang H.Y., Tan H., Zhou Y., Liu F.L., Chen F.Q.: Association of serum omentin-1 levels with coronary artery disease. Acta Pharmacol Sin 2011, 32, 873-878.

37. Zhou J.P., Tong X.Y., Zhu L.P., Luo J.M., Luo Y., Bai Y.P., et al.: Plasma omentin-1 level as a predictor of good coronary collateral circulation. Atheroscler Thromb 2017, DOI: 10.5551/jat.37440.

38. Zhang C., Zhu K.J., Liu J.L., Xu G.X., Liu W., Jiang F.X., et al.: Omentin-1 plasma levels and omentin-1 expression are decreased in psoriatic lesions of psoriasis patients. Arch Dermatol Res 2015, 307, 455-459.

39. Takahashi H., Tsuji H., Honma M., Ishida-Yamamoto A., Lizka H.: Increased plasma resistin and desreased omentin levels in Japanese patients with psoriasis. Arch Dermatol Res 2013, 305, 113-116.

40. Takahashi H., Tsuji H., Takahashi I., Hashimoto Y., Ishida-Yamamoto A., Izuka H.: Prevalence of obesity/adiposity in Japanese psoriasis patients: adiposity is correlated with the severity of psoriasis. Dermatol Sci 2009, 54, 61-63.

41. Ismail S.A., Mohamed S.A.: Serum levels of visfatin and omentin-1 in patients with psoriasis and their relation to disease severity. Br J Dermatol 2012, 167, 436-439.

42. Shang F.J., Wang J.P., Liu X.T., Zheng Q.S., Xue Y.S., Wang B., et al.: Serum omentin-1 levels are inversely associated with the presence and severity of coronary artery disease in patients with metabolic syndrome. Biomarkers 2011, 16, 657-662. 
43. Hida K., Wada J., Eguchi J., Ahang H., Baba M., Seida A.: Visceral adipose tissue-derived serine protease inhibitor: a unique insulin-sensitizing adipocytokine in obesity. Proc Natl Acad Sci USA 2005, 102, 10610-10615.

44. Silverman G.A., Bird P.I., Carrell R.W., Church F.C., Coughlin P.B., Gettins P.G.: The serpins are an expanding superfamily of structurally similar but functionally diverse proteins. Biol Chem 2001, 276, 33293-33296.

45. Li Q., Chen R., Moriya J., Yamakawa J., Sumino H., Kanda T., et al.: A novel adipocytokine, visceral adipose tissue-derived serine protease inhibitor (vaspin) and obesity. Int Med Res 2008, 36, 625-629.

46. Klöting N., Kovacs P., Kern M., Heiker J.T., Fasshauer M., Schon M.R., et al.: Central vaspin administration acutely reduces food intake and has sustained blood glucose-lowering effects. Diabetologia 2011, 54, 1819-1823.

47. Youn B.S., Kloting N., Kratzsch J., Lee N., Park J.W., Song E.S., et al.: Serum vaspin concentrations in human obesity and type 2 diabetes. Diabetes 2008, 57, 372-377.

48. Zvonic S., Lefevre M., Kilroy G., Floyd Z.E., De Lany J.P., Khaterpal I.: Secretome of primary cultures of human adiposederived stem cells. Mol Cell Proteomics 2007, 6, 18-28.

49. Gulcelik N.E., Karakaya J., Gedik A., Usman A., Gurlek A.: Serum vaspin levels in type 2 diabetic women in relation to microvascular complications. Eur J Endocrinol 2009, 160, 65-70.

50. Bluher M.: Vaspin in obesity and diabetes: pathophysiological and clinical significance. Endocrine 2012, 41, 176-182.

51. Li H.L., Peng W.H., Cui S.T., Lei H., Wei Y.D., Li W.M., et al.: Vaspin plasma concentrations and mRNA expressions in patients with stable and unstable angina pectoris. Clin Chem Lab Med 2011, 49, 1547-1554.

52. Maijer K.I., Neumann E., Muller-Ladner U., Drop D., Ramwadhdoebe T., Choi I.Y.K., et al.: Serum vaspin levels are associated with the development of clinically manifest arthritis in autoantibody-positive individuals. PLoS One 2015, 10, e0144932.

53. Saalbach A., Vester K., Rall K., Tremel J., Andereqq U., Beck-Sickinger A.G., et al.: Vaspin - a link of obesity and psoriasis? Exp Dermatol 2012, 21, 309-312.

54. Saalbach A., Tremel J., Herbert D., Schwede K., Wandell E., Schirmer C., et al.: Anti-inflammatory action of keratinocytederived vaspin. Relevance for the pathogenesis of psoriasis. Am J Pathol 2016, 186, 639-651.

55. Atasaven A., Kesli R.: Novel inflammatory markers in psoriasis vulgaris: vaspin, vascular adhesion protein-1 (VAP-1), and YKL-40. G Ital Dermatol Venereol 2016, 151, 244-250.

Received: 22.02.2017

Accepted: 3.07.2017

Otrzymano: $22.02 .2017 \mathrm{r}$.

Zaakceptowano: 3.07.2017 r.

How to cite this article

Kiluk P., Baran A., Flisiak I.: Role of omentin and vaspin in metabolic diseases in association with psoriasis. Dermatol Rev/Przegl Dermatol 2017, 104, 519-528. DOI: https://doi.org/10.5114/dr.2017.71217. 